\title{
POLA PENGGUNAAN OBAT BAHAN ALAM SEBAGAI TERAPI KOMPLEMENTER PADA PASIEN HIPERTENSI DI PUSKESMAS
}

\author{
Swandari Paramita*, Ronny Isnuwardana, Muhammad Khairul Nuryanto, \\ Ruth Djalung, Dewi Guntar Rachmawatiningtyas, Prilandy Jayastri \\ Labortorium Ilmu Kesehatan Masyarakat Fakultas Kedokteran Universitas Mulawarman \\ *Corresponding author emaill: swandariparamita@gmail.com
}

\begin{abstract}
Hypertension is a major health problem throughout the world, including Indonesia. The use of traditional medicine as part of the treatment of hypertension is increasing in the last decade. This is due to several factors, especially traditional medicine is a cheaper alternative with fewer undesirable side effects. This study tried to look at the pattern of use of natural medicine as a complementary therapy in hypertensive patients at the health center. The study is a descriptive study conducted in Puskesmas Sempaja Samarinda in the period September 2016, interviewing 62 hypertension patients with the use of natural medicine. The results showed $70.9 \%$ of patients with hypertension in the health center also uses natural medicines. All patients using herbal medicine which in theory is proven to lower blood pressure. However, there is no natural medicines used include standardized herbal medicine or phytopharmacy. Only $15.2 \%$ of patients using herbal medicine in accordance with the criteria BPOM regulation on herbal medicine. For conclusions, this study shows the patients still need to be educated for the use of natural medicine in the management of hypertension.
\end{abstract}

Keywords: pattern of drug use, natural medicine, hypertension

\begin{abstract}
ABSTRAK
Hipertensi merupakan masalah kesehatan utama di seluruh dunia, termasuk Indonesia. Penggunaan obat tradisional sebagai bagian dari pengobatan hipertensi semakin meningkat dalam dekade terakhir. Hal ini disebabkan adanya beberapa faktor, terutama harga obat tradisional yang dianggap lebih murah dengan efek samping yang dianggap lebih sedikit. Penelitian ini mencoba melihat pola penggunaan obat bahan alam sebagai terapi komplementer pada pasien hipertensi di Puskesmas. Penelitian merupakan studi deskriptif yang dilakukan di Puskesmas Sempaja Kota Samarinda pada periode September 2016, dengan mewawancarai 62 pasien hipertensi terkait penggunaan obat bahan alam. Hasil penelitian menunjukkan $70,9 \%$ pasien hipertensi di puskesmas juga menggunakan obat bahan alam. Seluruh pasien menggunakan obat bahan alam yang secara teori memang terbukti menurunkan tekanan darah. Namun demikian tidak ada obat bahan alam yang digunakan termasuk obat herbal terstandar atau fitofarmaka. Hanya 15,2\% pasien yang menggunakan obat bahan alam yang sesuai dengan peraturan BPOM tentang kriteria jamu. Kesimpulan penelitian ini menunjukkan masih perlunya edukasi penggunaan obat bahan alam di masyarakat untuk penatalaksanaan hipertensi.
\end{abstract}

Kata kunci: pola penggunaan obat, obat bahan alam, hipertensi

Submitted on: 4 April $2017 \quad$ Accepted on: 17 July 2017

DOI: https://doi.org/10.25026/jsk.v1i7.56

\section{PENDAHULUAN}

Hipertensi adalah suatu keadaan ketika tekanan darah di pembuluh darah meningkat secara kronis. Hal tersebut dapat terjadi karena jantung bekerja lebih keras memompa darah untuk memenuhi kebutuhan oksigen dan nutrisi tubuh. Jika dibiarkan, penyakit ini dapat mengganggu fungsi organ-organ lain, terutama organ-organ vital seperti jantung dan ginjal. Kriteria hipertensi yang digunakan merujuk pada kriteria diagnosis JNC VII 2003, yaitu hasil pengukuran tekanan darah sistolik $\geq 140$ 
mmHg atau tekanan darah diastolik $\geq 90$ $\mathrm{mmHg}$ (Kasper et al, 2015).

Prevalensi hipertensi di Indonesia berdasarkan hasil pengukuran tekanan darah sebesar 25,8\%. Sebagian besar $(63,2 \%)$ kasus hipertensi di masyarakat tidak terdiagnosis. Prevalensi hipertensi di Indonesia, tertinggi di Bangka Belitung (30,9\%), diikuti Kalimantan Selatan (30,8\%), Kalimantan Timur $(29,6 \%)$ dan Jawa Barat (29,4\%). Prevalensi hipertensi yang didapat melalui jawaban pernah didiagnosis tenaga kesehatan sebesar 9,4\%, sedangkan yang pernah didiagnosis tenaga kesehatan atau sedang minum obat hipertensi sendiri sebesar 9,5\%. Jadi, terdapat $0,1 \%$ penduduk yang minum obat sendiri, meskipun tidak pernah didiagnosis hipertensi oleh tenaga kesehatan (Kemenkes RI, 2013).

Data Riset Kesehatan Dasar (Riskesdas) tahun 2013 menunjukkan bahwa 30,4\% rumah tangga di Indonesia memanfaatkan pelayanan kesehatan tradisional, diantaranya $49 \%$ rumah tangga memanfaatkan ramuan obat tradisional. Sementara itu, Riskesdas tahun 2010 menunjukkan $60 \%$ penduduk Indonesia diatas usia 15 tahun menyatakan pernah minum jamu, dan 90\% diantaranya menyatakan adanya manfaat minum jamu (Aditama, 2014).

Di dunia internasional, penggunaan obat tradisional sudah sangat berkembang, cenderung meningkat, dan diperhitungkan sebagai komponen penting dalam pelayanan kesehatan dasar sejak dikeluarkannya Deklarasi Alma-Ata tahun 1978 dan dibentuknya program pengobatan tradisional oleh WHO (World Health Organization). Keseriusan pemerintah mendukung pemanfaatan obat tradisional terlihat dari berbagai peraturan yang ada, terutama sejak dikeluarkannya Peraturan Menteri Kesehatan tentang Saintifikasi Jamu pada tahun 2010
(Delima et al, 2012). Penggunaan obat tradisional sebagai bagian dari pengobatan hipertensi semakin meningkat dalam dekade terakhir. Hal ini disebabkan adanya beberapa faktor, terutama harga obat tradisional yang dianggap lebih murah dengan efek samping yang dianggap lebih sedikit (Hussaana et al, 2016). Berdasarkan hal tersebut diatas, maka penelitian ini bermaksud untuk mengetahui pola penggunaan obat bahan alam sebagai terapi komplementer pada pasien hipertensi di puskesmas.

\section{METODE PENELITIAN}

\section{Desain Penelitian}

Penelitian ini bersifat deskriptif untuk mengetahui pola penggunaan obat bahan alam sebagai terapi komplementer pada pasien hipertensi. Penelitian dilakukan di Puskesmas Sempaja Kota Samarinda sepanjang bulan September 2016.

\section{Subyek Penelitian}

Sampel yang digunakan dalam penelitian ini adalah penderita hipertensi dan memenuhi kriteria sampel yang ditetapkan oleh peneliti. Besar sampel ditentukan dengan menggunakan rumus besar sampel untuk data nominal. Dari perhitungan didapatkan besar sampel minimal adalah 45 orang. Pengambilan sampel dilakukan tanpa acak (nonprabability sampling) dengan teknik pengambilan consecutive sampling, yaitu pengambilan sampel pada subjek yang datang secara berurutan yang memenuhi kriteria penelitian hingga jumlah sampel minimal terpenuhi.

\section{Data dan Instrumen Penelitian}

$\begin{array}{llr}\text { Data dikumpulkan } & \text { dengan } \\ \text { menggunakan } & \text { kuesioner, } & \text { dimana } \\ \text { kuesioner yang digunakan } & \text { adalah }\end{array}$


kuesioner terbuka dan kuesioner tertutup. Instrumen penelitian yang dipakai dalam penelitian ini adalah lembar kuesioner dan kamera untuk mendokumentasikan sediaan obat bahan alam.

\section{Variabel Penelitian}

Variabel pada penelitian ini adalah sebagai berikut :

1. Pasien hipertensi

2. Jenis obat bahan alam

3. Bentuk sediaan obat bahan alam

\section{Definisi Operasional}

\section{Pasien Hipertensi}

Pasien hipertensi adalah pasien yang didiagnosis tekanan darah tinggi oleh dokter di Puskesmas Sempaja Kota Samarinda.

\section{Jenis Obat Bahan Alam}

Jenis obat bahan alam adalah jenis obat yang menggunakan bahan baku dari alam. Kriteria obyektif jenis obat bahan alam adalah:

a. Jamu: pada kemasan/wadah/ pembungkus/brosur terdapat logo "Ranting Daun Terletak Dalam Lingkaran" yang dicetak dengan warna hijau diatas dasar warna putih atau warna lain yang menyolok kontras, dan terdapat tulisan "Jamu".

b. Obat herbal terstandar: pada kemasan/wadah/pembungkus/brosur terdapat logo "Jari-jari Daun Sebanyak 3 Pasang Yang Terletak Dalam Lingkaran" yang dicetak dengan warna hijau diatas dasar warna putih atau warna lain yang menyolok kontras, dan terdapat tulisan "Obat Herbal Terstandar".

c. Fitofarmaka: pada kemasan/wadah/ pembungkus/brosur terdapat logo "Jari-jari Daun Yang Membentuk Bintang Yang Terletak Dalam Lingkaran" yang dicetak dengan warna hijau diatas dasar warna putih atau warna lain yang menyolok kontras, dan terdapat tulisan "Fitofarmaka".

d. Lain-lain: obat bahan alam yang tidak termasuk dalam jamu, obat herbal terstandar, dan fitofarmaka.

\section{Sediaan Obat Bahan Alam}

Sediaan obat bahan alam adalah bentuk obat bahan alam yang digunakan pasien. Kriteria obyektif sediaan obat bahan alam adalah:

a. Rajangan: sediaan berupa potongan simplisia atau campuran simplisia dengan sediaan galenik, yang sudah atau belum diseduh dengan air panas.

b. Pil: sediaan yang berbentuk bulat dan padat.

c. Tablet: sediaan padat, kompak, dengan bentuk tabung pipih, silindris atau bentuk lain.

d. Kapsul: sediaan yang terbungkus cangkang keras atau cangkang lunak.

e. Serbuk: sediaan berupa butiran homogen yang halus.

f. Larutan: sediaan berupa cairan yang mengandung satu atau lebih bahan alam terlarut.

g. Lain-lain: sediaan yang tidak termasuk ke dalam bentuk rajangan, pil, tablet, kapsul, serbuk, dan larutan.

\section{Pengolahan dan Penyajian Data}

Data yang diperoleh ditabulasikan menurut frekuensi distribusi dan presentase, pengolahan data dilakukan dengan menggunakan Microsoft Excel 2010. Data disajikan dalam bentuk narasi dan tabel.

\section{HASIL DAN PEMBAHASAN}

Hasil penelitian menunjukkan sebanyak 44 orang $(71 \%)$ pasien menggunakan obat bahan alam sebagai terapi komplementer hipertensi, seperti yang ditunjukkan pada Tabel 1 dan 2 . 
Sementara itu $58,7 \%$ bentuk sediaan obat bahan alam yang paling banyak digunakan pasien adalah berbentuk rajangan, seperti yang ditunjukkan pada Tabel 3.

Obat bahan alam yang paling sering digunakan adalah rajangan daun sirsak $(23,9 \%)$, seperti yang ditunjukkan pada Tabel 4. Seluruh obat bahan alam yang digunakan ternyata sudah sesuai dengan teori fitofarmaka tentang obat bahan alam yang terbukti khasiatnya dalam menurunkan tekanan darah, seperti yang ditunjukkan pada Tabel 5. Namun demikian hanya $15,2 \%$ obat bahan alam yang digunakan sesuai dengan peraturan BPOM tentang kemasan dan kriteria jamu yang baik (BPOM, 2004; BPOM, 2005).

Tabel 1. Distribusi penggunaan obat bahan alam yang digunakan sebagai terapi komplementer pada pasien hipertensi di Puskesmas Sempaja periode September 2016

\begin{tabular}{cccc}
\hline No & Penggunaan Obat Bahan Alam & N & \% \\
\hline 1 & Tidak menggunakan & 18 & $29,1 \%$ \\
2 & Menggunakan 1 macam & 42 & $67,7 \%$ \\
3 & Menggunakan 2 macam & 2 & $3,2 \%$ \\
\hline & Jumlah & 62 & $100 \%$ \\
\hline
\end{tabular}

Tabel 2. Distribusi jenis obat bahan alam yang digunakan sebagai terapi komplementer pada pasien hipertensi di Puskesmas Sempaja periode September 2016

\begin{tabular}{cccc}
\hline No & Jenis Obat Bahan Alam & $\mathbf{N}$ & $\mathbf{\%}$ \\
\hline 1 & Jamu & 7 & $15,2 \%$ \\
2 & Obat Herbal Terstandar & 0 & $0 \%$ \\
3 & Fitofarmaka & 0 & $0 \%$ \\
4 & Lain-Lain & 39 & $84,8 \%$ \\
\hline & Jumlah & 46 & $100 \%$ \\
\hline
\end{tabular}

Tabel 3. Distribusi sediaan obat bahan alam yang digunakan sebagai terapi komplementer pada pasien hipertensi di Puskesmas Sempaja periode September 2016

\begin{tabular}{cccc}
\hline No & Bentuk Sediaan Obat Bahan Alam & N & \% \\
\hline 1 & Rajangan & 27 & $58,7 \%$ \\
2 & Larutan & 12 & $26,1 \%$ \\
3 & Kapsul & 7 & $15,2 \%$ \\
4 & Pil & 0 & $0 \%$ \\
5 & Tablet & 0 & $0 \%$ \\
6 & Serbuk & 0 & $0 \%$ \\
7 & Lain-lain & 0 & $0 \%$ \\
\hline
\end{tabular}


Tabel 4. Distribusi obat bahan alam yang digunakan sebagai terapi komplementer dan kesesuaian dengan teori obat bahan alam serta peraturan BPOM pada pasien hipertensi di Puskesmas Sempaja periode September 2016

\begin{tabular}{cccccc}
\hline No & Jenis Obat Bahan Alam & N & $\%$ & $\begin{array}{c}\text { Kesesuaian Teori } \\
\text { Obat Bahan Alam }\end{array}$ & $\begin{array}{c}\text { Kesesuaian Peraturan } \\
\text { BPOM }\end{array}$ \\
\hline 1. & Rajangan daun sirsak & 11 & $23,9 \%$ & Sesuai & Tidak sesuai \\
2. & Rajangan bunga rosella kering & 6 & $13 \%$ & Sesuai & Tidak sesuai \\
3. & Air perasan jus seledri & 6 & $13 \%$ & Sesuai & Tidak sesuai \\
4. & Sari klorofil daun alfalfa & 6 & $13 \%$ & Sesuai & Tidak sesuai \\
5. & Ekstrak kulit manggis & 6 & $13 \%$ & Sesuai & Sesuai \\
6. & Rajangan daun salam & 5 & $10,9 \%$ & Sesuai & Tidak sesuai \\
7. & Jus mentimun & 3 & $6,6 \%$ & Sesuai & Tidak sesuai \\
8. & Rajangan buah mengkudu & 2 & $4,4 \%$ & Sesuai & Tidak sesuai \\
9. & Minyak jintan hitam & 1 & $2,2 \%$ & Sesuai & Sesuai \\
\hline \multicolumn{7}{c}{}
\end{tabular}

Pola Penggunaan Obat Bahan Alam

Hasil penelitian ini menunjukkan bahwa $70,9 \%$ pasien hipertensi menggunakan obat bahan alam sebagai terapi komplementer. Hal ini sesuai dengan penelitian oleh Pujiyanto (2008) yang juga menunjukkan bahwa seluruh pasien hipertensi dalam penelitiannya selain mengkonsumsi obat modern juga minum obat tradisional dari tumbuhtumbuhan. Penelitian oleh Diana et al (2008) di Bogor menemukan bahwa $48,9 \%$ responden penelitian mengonsumsi tanaman obat, dengan tujuan untuk mengobati hipertensi berada di urutan keempat $(11,4 \%)$. Sementara itu penelitian oleh Gusmira (2012) menunjukkan bahwa penurunan tekanan darah diastolik pada kelompok terapi kombinasi obat hipertensi konvensional bersama dengan obat bahan alam lebih baik dibandingkan kelompok terapi konvensional. Penelitian oleh Nurhayati dan Widowati (2016) menemukan bahwa pasien yang menjalani terapi farmakologis konvensional bersama dengan terapi herbal atau tradisional, ternyata memiliki kualitas hidup yang lebih baik (29\%), jika dibandingkan dengan pasien yang hanya menjalani terapi herbal atau tradisional.
Tingginya persentase pasien hipertensi yang menggunakan obat bahan alam sesuai dengan penelitian oleh Delima et al (2012) yang menunjukkan bahwa hipertensi berada di peringkat pertama dari 10 diagnosis penyakit yang diobati dengan jamu sebagai komplementer oleh dokter praktik jamu. Sementara itu penelitian oleh Widowati et al (2016) menunjukkan bahwa hipertensi berada di posisi ketiga untuk penyakit yang paling sering diberikan jamu oleh dokter praktik jamu.

\section{Obat Bahan Alam Sebagai Terapi Komplementer Hipertensi}

Hasil penelitian ini menemukan adanya 9 tumbuhan obat yang digunakan sebagai terapi komplementer hipertensi. Seluruh tumbuhan obat tersebut memang memiliki dasar teori yang kuat untuk efek antihipertensi. Daun sirsak merupakan obat bahan alam yang paling sering digunakan, disusul oleh rosella, seledri, alfalfa, kulit manggis, daun salam, mentimun, buah mengkudu dan jintan hitam. Hasil penelitian ini sedikit berbeda dengan penelitian oleh Pujianto (2008) Tumbuhan obat yang diminum antara lain adalah sirih, mahkota dewa, salam, kecapi, mustajab, kumis kucing, keji beling, ceplukan, belimbing dan 
mentimun. Penelitian oleh Gusmira (2012) menemukan bahwa mentimun adalah obat bahan alam yang paling sering digunakan untuk hipertensi, disusul oleh bawang putih dan rosella. Sementara itu penelitian oleh Widowati et al (2014) menunjukkan bahwa dokter yang melakukan praktik komplementeralternatif, jamu yang terbanyak diberikan untuk pasien hipertensi adalah seledri. Urutan persentase terbanyak penggunaan jamu untuk hipertensi adalah yang mengandung seledri, kumis kucing, pegagan, bawang putih, dan mengkudu.

Kerasionalan dari ramuan hipertensi adalah adanya komponen tanaman obat sebagai diuretik, anti andregenik, simpatikolitik dan lancarnya peredaran darah. Komisi Nasional Saintifikasi Jamu telah menyusun FJA (Formula Jamu Antihipertensi) yang mengandung komposisi yaitu herba seledri (Apium graveolens L.), daun kumis kucing (Orthosiphon aristatus (Blume) Miq.), herba pegagan (Centella asiatica (L.) Urb.), herba meniran (Phyllanthus niruri L.), rimpang temu lawak (Curcuma zanthorrhiza Roxb.) dan rimpang kunyit (Curcuma longa L.) (Hussaana et al, 2016).

Hasil penelitian ini menemukan bahwa hanya $15,2 \%$ obat bahan alam yang digunakan sesuai dengan peraturan BPOM tentang kemasan dan kriteria jamu yang baik. Seledri sendiri merupakan komponen utama produk fitofarmaka satu-satunya untuk hipertensi, yaitu Tensigard®. Produk ini ternyata tidak banyak digunakan oleh dokter, walaupun merupakan suatu sediaan yang sudah resmi dapat digunakan dalam pelayanan kesehatan formal. Penggunaan fitofarmaka oleh dokter kurang menggembirakan, walaupun telah didukung evidence base uji klinik. Hal inilah yang menyebabkan industri masih enggan mengembangkan produknya ke arah fitofarmaka (Widowati et al, 2014).

\section{Sirsak (Annona muricata L.)}

Hasil penelitian ini menunjukkan bahwa pasien hipertensi menggunakan rajangan daun sirsak untuk menurunkan tekanan darah. Hal ini sesuai dengan penelitian yang menunjukkan bahwa ekstrak air daun sirsak dapat menurunkan secara signifikan tekanan darah tanpa mempengaruhi denyut jantung (Patel dan Patel, 2016). Efek hipotensif dari ekstrak air daun sirsak melalui mekanisme perifer yang melibatkan antagonis ion kalsium dengan blokade kanal ion kalsium (Nwokocha et al, 2012). Efek hipotensif daun sirsak disebabkan oleh kandungan alkaloid seperti coreximine, anomurine, dan reticulin, serta beberapa komponen minyak esensial seperti b-caryophyllene (Coria-Tellez et al, 2016).

\section{Rosella (Hibiscus sabdariffa L.)}

Hasil penelitian ini menunjukkan bahwa pasien hipertensi menggunakan rajangan bunga rosella kering untuk menurunkan tekanan darah. Hal ini sesuai dengan penelitian yang menunjukkan bahwa ekstrak air bunga rosella memiliki efek antihipertensi (Mojiminiyi et al, 2007). Efek antihipertensi rosella melalui berbagai mekanisme, yaitu peningkatan produksi nitrit oksida, penghambatan kanal ion kalsium dan pembukaan kanal ATP kalium (Al Disi et al, 2016). Rosella juga memiliki efek diuretik, yang mekanisme kerjanya serupa dengan obat penurun tekanan kelompok diuretik (DaCosta-Rocha et al, 2014), dan efek penghambatan pada Angiotensin Converting Enzyme (ACE), yang mekanisme kerjanya serupa dengan obat penurun tekanan kelompok ACE inhibitor (Ojeda et al, 2010). Kandungan anthocyanins yang terkandung dalam rosella berperan dalam efek 
antihipertensi, selain juga terdapat peran dari polifenol dan hibiscus acid (Hopkins et al, 2013).

\section{Seledri (Apium graveolens L.)}

Hasil penelitian ini menunjukkan bahwa pasien hipertensi menggunakan air perasan jus seledri untuk menurunkan tekanan darah. Hal ini sesuai dengan FJA (Formula Jamu Antihipertensi) yang disusun oleh Komisi Nasional Saintifikasi Jamu, mengandung komposisi diantaranya herba seledri. Tumbuhan ini mengandung flavonoid (apiin dan apigenin) serta kumarin (Hussaana et al, 2016). Efek antihipertensi seledri melalui mekanisme penghambatan kanal ion kalsium (Tashakori-Sabzevara et al, 2016), dan penghambatan pada ACE (Simaratanamongkol et al, 2014).

\section{Alfalfa (Medicago sativa $\mathbf{L}$.)}

Hasil penelitian ini menunjukkan bahwa pasien hipertensi menggunakan sari klorofil dari daun alfalfa untuk menurunkan tekanan darah. Hal ini sesuai dengan penelitian yang menunjukkan bahwa alfalfa memiliki efek untuk mengurangi tekanan darah pada tikus percobaan yang dibuat hipertensi (Martinez et al, 2016).

\section{Manggis (Garcinia $x$ mangostana $\mathbf{L}$.)}

Hasil penelitian ini menunjukkan bahwa pasien hipertensi menggunakan ekstrak kulit manggis untuk menurunkan tekanan darah. Hal ini sesuai dengan penelitian tentang mekanisme kerja manggis sebagai antihipertensi melalui antagonis ion kalsium (Hemshekhar et al, 2011). Komponen fenolik dari manggis dapat mencegah terjadinya vasokonstriksi pembuluh darah melalui mekanisme vasodilatasi langsung dan pembangkitan nitrit oksida (Abdallah et al, 2016).

\section{Daun Salam (Syzygium polyanthum (Wight) Walp.)}

Hasil penelitian ini menunjukkan bahwa pasien hipertensi menggunakan rajangan daun salam untuk menurunkan tekanan darah. Hal ini sesuai dengan penelitian di Kutai Kartanegara, Kalimantan Timur, yang menunjukkan bahwa masyarakat disana menggunakan daun salam sebagai tumbuhan obat untuk diare, kencing manis dan asam urat (Widyawati dan Rizal, 2015). Mekanisme kerja daun salam sebagai antihipertensi melalui pelibatan reseptor beta adrenergik dan kolinergik dengan produksi nitrit oksida (Ismail et al, 2013), dan melalui penghambatan ACE (Puspitasari et al, 2015).

\section{Mentimun (Cucumis sativus L.)}

Hasil penelitian ini menunjukkan bahwa pasien hipertensi menggunakan jus mentimun untuk menurunkan tekanan darah. Hal ini sesuai dengan penelitian yang menunjukkan bahwa pemberian jus mentimun dapat menurunkan secara signifikan tekanan darah diastolik antara kelompok perlakuan dibandingkan dengan kelompok kontrol (Muniroh et al, 2007).

\section{Mengkudu (Morinda citrifolia L.)}

Hasil penelitian ini menunjukkan bahwa pasien hipertensi menggunakan rajangan buah mengkudu untuk menurunkan tekanan darah. Hal ini sesuai dengan penelitian di Kutai Kartanegara, Kalimantan Timur, yang menunjukkan bahwa masyarakat disana menggunakan buah mengkudu sebagai tumbuhan obat untuk menurunkan tekanan darah tinggi, kolesterol, melancarkan peredaran darah dan membersihkan kandung kemih (Widyawati dan Rizal, 2015). Pemberian jus mengkudu menurunkan tekanan darah tinggi secara signifikan, terutama pada tekanan darah sistolik (Ali et al, 2016). 
Ekstrak daun dan buah mengkudu dapat menurunkan tekanan darah hewan coba yang dibuat menjadi hipertensi (Wigati et al, 2017). Mekanisme kerja jus mengkudu sebagai antihipertensi melalui penghambatan ACE (Singh, 2012).

\section{Jintan Hitam (Nigella sativa L.)}

Hasil penelitian ini menunjukkan bahwa pasien hipertensi menggunakan minyak jintan hitam untuk menurunkan tekanan darah. Hal ini sesuai dengan penelitian bahwa pemberian minyak jintan hitam selama 8 minggu dapat menurunkan tekanan darah (Huseini et al, 2013). Mekanisme kerja ekstrak jintan hitam sebagai antihipertensi melalui mekanismenya sebagai diuretik (Tembhurne et al, 2014), dan melalui penghambatan kanal ion kalsium (Al Disi et al, 2016).

\section{KESIMPULAN}

Sebagian besar pasien hipertensi menggunakan obat bahan alam selain obat hipertensi konvensional. Seluruh pasien menggunakan obat bahan alam yang secara teori memang terbukti menurunkan tekanan darah. Namun demikian hanya $15,2 \%$ pasien yang menggunakan obat bahan alam sesuai dengan peraturan BPOM tentang kriteria jamu. Hasil penelitian ini menunjukkan masih perlunya edukasi penggunaan obat bahan alam di masyarakat sebagai terapi komplementer untuk hipertensi.

\section{DAFTAR PUSTAKA}

[1]. Abdallah HM, El-Bassossy HM, Mohamed GA, El-Halawany AM, Alshali KZ, Banjar ZM. (2016). Phenolics from Garcinia mangostana alleviate exagerrated vasoconstriction in metabolic syndrome through direct vasodilatation and nitric oxide generation. BMC Complementary and Alternative Medicine. 16: 359.
[2]. Aditama TY. (2014). Jamu dan Kesehatan. Badan Penelitian dan Pengembangan Kesehatan Kementerian Kesehatan Republik Indonesia. Jakarta.

[3]. Al Disi SS, Anwar MA, Eid AH. (2016). Anti-hypertensive Herbs and their Mechanisms of Action: Part I. Frontier of Pharmacology. 6:323. doi: 10.3389/fphar.2015.00323.

[4]. Ali M, Kenganora M, Manjula SN. (2016). Health Benefits of Morinda citrifolia (Noni): A Review Pharmacognosy Journal. 8(4): 321-334.

[5]. Badan Pengawas Obat dan Makanan [BPOM]. (2004). Peraturan Kepala Badan Pengawas Obat dan Makanan No. HK.00.05.4.2411 tentang Ketentuan Pokok Pengelompokan dan Penandaan Obat Bahan Alam Indonesia.

[6]. Badan Pengawas Obat dan Makanan [BPOM]. (2005). Keputusan Kepala Badan Pengawas Obat dan Makanan No. HK.00.05.41.1384 tentang Kriteria dan Tatalaksana Pendaftaran Obat Tradisional, Obat Herbal Terstandar, dan Fitofarmaka.

[7]. Coria-Tellez AV, Montalvo-Gonzalez E, Yahia EM, Obledo-Vazquez EN. (2016). Annona muricata: A comprehensive review on its traditional medicinal uses, phytochemicals, pharmacological activities, mechanisms of action and toxicity. Arabian Journal of Chemistry. http://dx.doi.org/10.1016/j.arabjc.2016.01.00 4.

[8]. Da-Costa-Rocha I, Bonnlaender B, Sievers H, Pischel I, Heinrich M. (2014). Hibiscus sabdariffa L. - A phytochemical and pharmacological review. Food Chemistry. 165: 424-443.

[9]. Delima D, Widowati L, Astuti Y, Siswoyo H, Gitawati R, Purwadianto A. (2012). Gambaran Praktik Penggunaan Jamu Oleh Dokter di Enam Provinsi di Indonesia. Buletin Penelitian Kesehatan. 40(3): 109122.

[10]. Diana R, Roosita K, Khomsan A. (2008). Life Style, Supplement Consumption, Traditional Medicine (Jamu), Medical Plants, and Health Status of Elderly at Bogor District. Jurnal Gizi dan Pangan. 3(2): 118123.

[11]. Gusmira S. (2012). Evaluasi penggunaan antihipertensi konvensional dan kombinasi konvensional-bahan alam pada pasien hipertensi di puskesmas wilayah Depok. Makara Kesehatan. 16(2): 77-83. 
[12]. Hemshekhar M, Sunitha K, Santhosh MS, Devaraja S, Kemparaju K, Vishwanath BS, Niranjana SR, Girish KS. (2011). An overview on genus Garcinia: phytochemical and therapeutical aspects. Phytochem Rev. 10: 325-351.

[13]. Hopkins AL, Lamm MG, Funk JL, Ritenbaugh C. (2013). Hibiscus sabdariffa L. in the treatment of hypertension and hyperlipidemia: A comprehensive review of animal and human studies. Fitoterapia. 85: 84-94.

[14]. Huseini HF, Amini M, Mohtashami R, Ghamarchehre ME, Sadeqhi Z, Kianbakht S, Huseini AF. (2013). Blood Pressure Lowering Effect of Nigella sativa L. Seed Oil in Healthy Volunteers: A Randomized, Double-Blind, Placebo-controlled Clinical Trial. Phytotherapy Research. 27: 18491853.

[15]. Hussaana A, Sarosa H, Indrayani UD, Chodidjah C, Widiyanto B, Pertiwi D. (2016). Formula Jamu Antihipertensi and captopril are equally effective in patients with hypertension. Universa Medicina. 35(2): 81-88.

[16]. Ismail A, Mohamed M, Sulaiman SA, WanAhmad WAN. (2013). Autonomic Nervous System Mediates the Hypotensive Effects of Aqueous and Residual Methanolic Extracts of Syzygium polyanthum (Wight) Walp. var. polyanthum Leaves in Anaesthetized Rats. Evidence-Based Complementary and Alternative Medicine. http://dx.doi.org/10.1155/2013/716532.

[17]. Kasper DL, Hauser SL, Jameson JL, Fauci AS, Longo DL, Loscalzo J. (2015). Harrison's Principles of Internal Medicine. Nineteenth Edition. 1669-1680. McGraw Hill Education. New York.

[18]. Kementerian Kesehatan RI. (2013). Riset Kesehatan Dasar Tahun 2013. Badan Penelitian dan Pengembangan Kesehatan. 72-77. Kementerian Kesehatan RI. Jakarta.

[19]. Martinez R, Kapravelou G, Porres JM, Melesio AM, Heras L, Cantarero S, Gribble FM, Parker H, Aranda P, Lopez-Jurado M. (2016). Medicago sativa L., a functional food to relieve hypertension and metabolic disorders in a spontaneously hypertensive rat model. Journal of Functional Foods. 26: 470-484.

[20]. Mojiminiyi FBO, Dikko M, Muhammad BY, Ojobor PD, Ajagbonna OP, Okolo RU, Igbokwe UV, Mojiminiyi UE, Fagbemi MA, Bello SO, Anga TJ. (2007). Antihypertensive effect of an aqueous extract of the calyx of Hibiscus sabdariffa. Fitoterapia. 78: 292-297.

[21]. Muniroh L, Wirjatmadi B, Kuntoro K. (2007). Pengaruh Pemberian Jus Buah Belimbing dan Mentimun terhadap Penurunan Tekanan Darah Sistolik dan Diastolik Penderita Hipertensi. The Indonesian Journal of Public Health. 4(1): 25-34

[22]. Nurhayati N, Widowati L. (2016). Herbal therapy and quality of life in hypertension patients at health facilities providing complementary therapy. Health Science Journal of Indonesia. 7: 32-36.

[23]. Nwokocha CR, Owu DU, Gordon A, Thaxter K, McCalla G, Ozolua RI, Young L. (2012). Possible mechanisms of action of the hypotensive effect of Annona muricata (soursop) in normotensive Sprague-Dawley rats. Pharmaceutical Biology. 50(11): 14361441.

[24]. Ojeda D, Jiménez-Ferrer E, Zamilpa A, Herrera-Arellano A, Tortoriello J, Alvarez L. (2010). Inhibition of angiotensin convertin enzyme (ACE) activity by the anthocyanins delphinidin- and cyanidin-3-Osambubiosides from Hibiscus sabdariffa. Journal of Ethnopharmacology. 127: 7-10.

[25]. Patel S, Patel JK. (2016). A review on a miracle fruits of Annona muricata. Journal of Pharmacognosy and Phytochemistry. 5(1): 137-148.

[26]. Pujiyanto P. (2008). Faktor Sosio Ekonomi yang Mempengaruhi Kepatuhan Minum Obat Antihipertensi. Jurnal Kesehatan Masyarakat Nasional. 3(3): 139-144.

[27]. Puspitasari RT, Hakim R, Damayanti DS. (2015). Studi In Silico Dekokta Daun Salam (Syzygium polyanthum) Terhadap Angiotensin Converting Enzyme. Jurnal Kedokteran Komunitas. 3(1): 191-199.

[28]. Simaratanamongkol A, Umehara K, Noguchi H, Panichayupakaranant P. (2014). Identification of a new angiotensinconverting enzyme (ACE) inhibitor from Thai edible plants. Food Chemistry. 165: 9297.

[29]. Singh DR. (2012). Morinda citrifolia L. (Noni): A review of the scientific validation for its nutritional and therapeutic properties. Journal of Diabetes and Endocrinology. 3(6): 77-91.

[30]. Tashakori-Sabzevara F, Razavib BM, Imenshahidic M, Daneshmandia M, Fatehia H, Sarkarizi YE, Mohajeric SA. (2016). Evaluation of mechanism for 
antihypertensive and vasorelaxant effects of hexanic and hydroalcoholic extracts of celery seed in normotensive and hypertensive rats. Brazilian Journal of Pharmacognosy. 26: 619-626.

[31]. Tembhurne SV, Feroz S, More BH, Sakarkar DM. (2014). A review on therapeutic potential of Nigella sativa (kalonji) seeds. Journal of Medicinal Plants Research. 8(3): 167-177.

[32]. Widowati L, Siswanto S, Delima D, Siswoyo H. (2014). Evaulasi Praktik Dokter yang Meresepkan Jamu Untuk Pasien Penderita Penyakit Degenerative di 12 Propinsi. Media Litbangkes. 24(2): 95-102.
[33]. Widyawati AT, Rizal M. (2015). Upaya pemberdayaan apotik hidup di perkotaan melalui deskripsi dan manfaat tanaman obat. Prosiding Seminar Nasional Masyarakat Biodiversitas Indonesia. 1(8): 1890-1895.

[34]. Wigati D, Anwar K, Sudarsono S, Nugroho AE. (2017). Hypotensive Activity of Ethanolic Extracts of Morinda citrifolia L. Leaves and Fruit in Dexamethasone-Induced Hypertensive Rat. Journal of EvidenceBased Complementary \& Alternative Medicine. 22(1): 107-113. 